\title{
Kesejahteraan Rakyat dan Implementasi Kebijakan Transportasi Laut di Jawa Barat
}

\author{
Awing Asmawi \\ Universitas Padjadjaran \\ awingasmawi@ymail.com
}

\begin{abstract}
This article discusses how public policy on transport can have a welfare impact on society. The study of marine transportation is conducted in West Java, Indonesia. This is important because the development of marine transportation services can have a very close relationship with social welfare and economic growth of a region. This study uses a case study method of activities which is the implementation of the West Java government program to its people regarding sea transportation. Interview, observation, and document analysis are used to collect data. A face-to-face interview using a questionnaire has been developed for this study. The study findings show that in addition to designing and implementing the sea transportation development plan in West Java, the marine transportation policy also involves the national government of Indonesia. All marine transportation policy is intended primarily for the welfare of the community. However, here and there there are still shortcomings that need to be improved
\end{abstract}

Keywords: Public policy, sea transportation, West Java, policy implementation

\begin{abstract}
Abstrak
Artikel ini membahas bagaimana kebijakan publik tentang transportasi dapat mempunyai dampak kesejahteraan bagi masyarakat. Kajian tentang transportasi laut ini dilakukan di Jawa Barat, Indonesia. Hal ini penting karena pembangunan layanan transportasi laut dapat memiliki keterkaitan yang sangat erat dengan kesejahteraan sosial dan pertumbuhan ekonomi suatu wilayah. Kajian ini menggunakan metode kajian kasus tentang kegiatan-kegiatan yang merupakan implementasi dari program pemerintah Jawa Barat kepada masyarakatnya mengenai transportasi laut. Wawancara, pengamatan, dan analisis dokumen digunakan untuk mengumpulkan data. Wawancara tatap muka memakai daftar pertanyaan telah dikembangkan untuk kajian ini. Temuan kajian menunjukkan bahwa selain merancang sendiri dan melaksanakan rencana pembangunan transportasi laut di Jawa Barat, kebijakan transportasi laut pun melibatkan pemerintah nasional Indonesia. Kesemua kebijakan transportasi laut tersebut ditujukan terutama untuk kesejahteraan masyarakat. Namun demikian, di sanasini masih ada kekurangan yang harus terus diperbaiki.
\end{abstract}

Kata Kunci: Kebijakan publik, transportasi laut, Jawa Barat, implementasi kebijakan

\section{A. PENDAHULUAN}

Di beberapa daerah di Indonesia penyediaan layanan transportasi, termasuk transportasi laut, masih terkendala dengan jumlah alokasi anggaran yang terbatas. Hal ini mengingat karena sebagian anggaran banyak dialokasikan untuk membiayai belanja pegawai pada daerah masing-masing (www.jabarprov.go.id, 2014). Keberadaan 
pelabuhan untuk melayani transportasi laut masih terbatas pada pelayaran lokal dan regional. Tercatat lima pelabuhan yang terdapat di Jawa Barat, yaitu Pelabuhan Cirebon, Pelabuhan Indramayu, Pelabuhan Pangandaran, Pelabuhan Pamanukan, dan Pelabuhan Ratu. Secara umum terdapat peningkatan pada jumlah kapal dan bongkar barang, namun terdapat penurunan pada jumlah penumpang yang naik dan turun. ${ }^{1}$

Sementara itu, salah satu tolok ukur keberhasilan pembangunan di bidang ekonomi yang diperlukan untuk evaluasi dan perencanaan ekonomi makro, biasanya dilihat dari pertumbuhan ekonomi yang tercermin dari nilai Produk Domestik Regional Bruto (PDRB), baik atas dasar harga berlaku maupun atas dasar harga konstan. Pertumbuhan ekonomi Provinsi Jawa Barat, cenderung melambat, yaitu sebesar 6,33\% di Tahun 2013 menjadi 5,07\% di Tahun 2014. Pertumbuhan terjadi pada seluruh lapangan usaha. Informasi dan Komunikasi merupakan lapangan usaha yang mengalami pertumbuhan tertinggi sebesar 17,47 persen, diikuti oleh Jasa Kesehatan dan Kegiatan Sosial sebesar 15,78 persen dan Jasa Pendidikan sebesar 14,43 persen. Struktur perekonomian Jawa Barat menurut lapangan usaha tahun 2014 didominasi oleh tiga lapangan usaha utama yaitu: Industri Pengolahan (43,57 persen); Perdagangan Besar-Eceran dan Reparasi Mobil-Sepeda Motor (15,24 persen) dan Pertanian, Kehutanan dan Perikanan (8,72 persen) (www.jabar.bps.go.id., 2016).

Di samping fakta tersebut di atas kondisi perekonomian yang tercermin dari nilai PDRB atas dasar harga konstan Provinsi Jawa Barat pada Tahun 2016 menempati urutan yang ke-22 secara nasional (www.id.wikipedia.org) namun kondisi tersebut tidak serta merta mencerminkan tingkat kesejahteraan yang tergambar dari nilai IPM Provinsi Jawa Barat yang menempati peringkat ke-12 secara nasional (www.bps.go.id., 2016). Nilai IPM merupakan salah satu alat ukur yang dianggap dapat merefleksikan status pembangunan manusia atau kesejahteraan manusia. IPM merupakan suatu indeks komposit yang mencakup tiga komponen pembangunan manusia yang dianggap sangat mendasar yaitu angka harapan hidup (longevity), pengetahuan (knowledge), dan standar hidup layak (decent living). Dengan demikian, nilai PDRB suatu daerah belum tentu mengambarkan kondisi kesejahteraan rakyat di daerah tersebut yang tercermin dari nilai

\footnotetext{
${ }^{1}$ http://www.jabarprov.go.id/root/rpimd/PerubahanRPJMDBABII.doc [7/6/17].
} 
IPM (Asmawi et.al., 2018). Kondisi demikian diduga terjadi disebabkan oleh kualitas dan kuantitas layanan transportasi yang belum sesuai dengan harapan yang pada akhirnya akan mempengaruhi tingkat kesejahteraan masyarakat.

\section{B. LANDASAN TEORI}

Transportasi adalah seperangkat fasilitas berupa barang dan jasa yang disediakan untuk kepentingan publik atau masyarakat dalam layanan pengangkutan. Transportasi adalah saham atas layanan atau fasilitas dasar dan peralatan modal pengangkutan yang dibutuhkan oleh masyarakat sebagai pelaksanaan fungsi suatu negara atau daerah, sebagai contoh penyediaan transportasi darat, laut dan udara, dan pekerjaan umum yang sama yang diperlukan dalam sistem transportasi (Srinivasu, 2013: 82; Asmawi et.al., 2018).

Sebetulnya, hakekat proyek-proyek pembangunan yang dilaksanakan pemerintah adalah dalam rangka untuk meningkatkan kesejahteraan masyarakat. Kesejahteraan masyarakat akan naik apabila ada kenaikan nilai produk suatu barang dan jasa yang dihasilkan oleh kegiatan-kegiatan pembangunan seperti proyek transportasi (Anwar, 2011: 52; Asmawi et.al., 2017).

Transportasi yang baik membantu untuk meningkatkan produktivitas dan menurunkan biaya dalam kegiatan langsung produktif ekonomi. Penyediaan yang memadai atas transportasi yang baik dapat membantu meningkatkan produktivitas dan menurunkan biaya langsung produksi yang lebih rendah, yang selanjutnya dapat memperluas atau meningkatkan pertumbuhan (Gopalakrishna dan Leelavathi, 2011).

Transportasi berpengaruh pada investasi dan pertumbuhan melalui peningkatan produktivitas dan efisiensi. Pembangunan transportasi akan meningkatkan keuntungan bagi perusahaan karena adanya penurunan biaya produksi dan meningkatkan perluasan pasar. Dengan adanya perluasan produksi tersebut maka berdampak pada peningkatan pertumbuhan yang selanjutnya akan mempengaruhi tingkat kesejahteraan (Srinivasu, 2013: 86).

Untuk melihat hal ini, diperlukan teori-teori ekonomi dan sosial seperti teori ketergantungan sumber daya. Menurut teori ini, suatu organisasi akan mempunyai serangkaian hubungan-hubungan dan akan diikat oleh hubungan-hubungan lain atau oleh posisinya dalam sistem jaringan yang lebih luas. Organisasi-organisasi melekat 
secara khas dalam jaringan ganda. Seringkali jaringan-jaringan tersebut tumpang tindih satu sama lain. Perspektif kelas sosial dalam analisis jaringan sosial mempercayai argumentasi bahwa hubungan ekonomi, politik dan sosial di antara kelompok elit menciptakan suatu kekuasaan elit yang padu (Mills, 1959). Perspektif ketergantungan sumber daya melihat organisasi sebagai aktor dan individu utama sebagai agen secara simbolik; sedangkan menurut perspektif kelas sosial, individu dipandang sebagai aktor utama dan organisasi sebagai sarana. Jaringan antar-organisasi yang dibentuk dari asosiasi ini merupakan kendaraan untuk memperkuat integrasi elit kekuasaan dan mempertahankan kendali institusi sosial kunci (Perry, 2002: 16). Itulah gambaran tentang keterlibatan pemerintah dalam bidang transportasi, yaitu bagaimana pemerintah dapat mengendalikan masalah transportasi ini.

Secara teoretis, dalam rangka integrasi elit dan kekuasaan seperti tersebut di atas, lembaga-lembaga (institutions) berinteraksi dengan jaringan sosial (social networks) dan norma yang ada untuk membentuk tindakan ekonomi (economic action). Victor Nee (2005: 52) menjelaskan bahwa yang dimaksud dengan institusi adalah sistem dominan dari elemen-elemen yang bersifat formal dan informal seperti kebiasaan, kesepakatankesepakatan, norma-norma, dan kepercayaan bersama (shared beliefs), di mana para aktor mendasarkan tindakannya ketika memenuhi kepentingan-kepentingannya. Melalui definisi ini, Victor Nee (2005: 56) memandang institusi sebagai struktur-struktur sosial yang menyediakan pedoman untuk tindakan bersama dengan cara mengatur kepentingan masing-masing orang dan memperkuat hubungan antar mereka, karena perilaku seseorang dipengaruhi oleh orang lain. Kerangka institusi inilah yang membentuk perilaku ekonomi masyarakat. Melalui konsepsi ini, Victor Nee memperbaiki konsep yang dirintis Douglas C. North yang terlalu menggunakan perspektif ekonomi dalam melihat bahwa perilaku ekonomi tidak dipengaruhi oleh pihak lain, selain pasar (market) dan negara (state) (Toboso, 2001: 765-784).

Victor Nee (2005: 55-57), yang merupakan generasi mutakhir dalam teori institusional baru ini (new institutionalism), menjelaskan bahwa perubahan institusi (institutional change) tidak hanya melibatkan pembentukan ulang aturan-aturan formal tapi secara fundamental menuntut adanya pengaturan kembali (rearrangement) dari kepentingan-kepentingan, norma-norma, dan kekuasaan. Semua proses kemunculan, penolakan (resistensi), dan transformasi dari struktur institusi ini berdasarkan pada 
rasionalitas yang kontekstual (context-bond rationality), yaitu rasionalitas yang berdasarkan konteks masyarakat tertentu dan tertanam dalam hubungan-hubungan interpersonal.

Oleh karena itu, demi mengawal fungsi institusi-institusi ini, implementasi kebijakan publik seperti masalah transportasi, perlu dilandasi dengan teori sistem (systems theory). Di sini, fungsi adalah "suatu proses yang bertugas memelihara suatu sistem yang lebih besar di mana ia jumpai, atau untuk mempertahankan unsur atau subsistem, atau tujuan suatu subsistem di dalam mengejar tujuan suatu sistem, atau tujuan subsistem di dalamnya" (Deutsch, 1986). Lebih jauh Deutsch menjelaskan tentang fungsi negara yang dapat diidentifikasi dalam sembilan (9) fungsi mulai dari fungsi pemeliharaan tatanan, pengejaran kekuasaan, kemakmuran dan kedudukan yang lebih tinggi, pengaturan kesejahteraan melalui pelayanan sosial, peningkatan kemampuan masyarakat sampai dengan pencapaian tujuan tertentu seperti kemerdekaan. Dalam kaitannya dengan fungsi memelihara tatanan dan mempertahankan kekuasaan, maka komunikasi politik yang dijalankan elite negara, menjadi sangat menentukan dalam mencapai kedua tujuan tersebut.

Fungsi memang bagian pokok dari teori sistem. Sistem sendiri adalah suatu kesatuan yang terdiri komponen-komponen atau elemen-elemen yang dihubungkan bersama untuk memudahkan aliran informasi, materi atau energi. Kata 'sistem' yang berasal dari bahasa Latin (systèma) dan bahasa Yunani (sustèma) ini sering dipergunakan untuk menggambarkan suatu set entitas yang berinteraksi, di mana suatu model matematika seringkali bisa dibuat.

Ciri kesatuan yang terdiri dari bagian-bagian yang mempunyai fungsi masingmasing ini memang inti dari pengertian sistem. Ludwig Von Bertalanffy menyatakan bahwa sistem adalah seperangkat unsur-unsur yang terikat dalam suatu antar relasi. Begitu pula Anatol Rapoport yang menjelaskan bahwa sistem adalah suatu kumpulan kesatuan dan perangkat yang berhubungan satu sama lain. Selanjutnya, L. Ackof menyatakan bahwa, sistem adalah setiap kesatuan, secara konseptual atau fisik, yang terdiri dari bagian-bagian dalam keadaan saling tergantung (inter-dependent) satu sama lain (Mustari \& Rahman, 2010).

Teori sistem memang lebih banyak dipergunakan pada kajian organisasi atau kelembagaan. Namun, untuk lebih dapat mendalami suatu kebijakan, maka teori sistem juga dapat dipergunakan untuk mendalami dan mengevaluasi sebuah 
kebijakan publik. Demikianlah sehingga terurai bagaimana tujuan dari kebijakan publik itu, input untuk kebijakan publik itu, bagaimana suatu kebijakan publik itu lahir yang menunjukkan prosesnya, bagaimana output kebijakan publik, apa batasbatas suatu kebijakan publik, bagaimana mekanisme pengendalian atau umpan balik untuk suatu kebijakan publik, bagaimana lingkungan suatu kebijakan publik, dan bagaimana subsistem dan supersistem dari kebijakan publik tersebut.

Misalnya, mengenai kebijakan transportasi di Jawa Barat, dapat ditanyakan bagaimana tujuan dari kebijakan transportasi di Jawa Barat itu, input apa saja untuk kebijakan transportasi di Jawa Barat itu, bagaimana kebijakan transportasi di Jawa Barat itu lahir yang menunjukkan prosesnya, bagaimana output kebijakan transportasi di Jawa Barat, apa batas-batas kebijakan transportasi di Jawa Barat, bagaimana mekanisme pengendalian atau umpan balik untuk kebijakan transportasi di Jawa Barat, bagaimana lingkungan kebijakan transportasi di Jawa Barat, dan bagaimana subsistem dan supersistem dari kebijakan transportasi di Jawa Barat.

Ada beberapa acuan untuk dijadikan perbandingan bagi kajian transportasi. Misalnya kajian Amrul Alam (2011) yang berjudul "Analisis Prioritas Kebijakan Transportasi Kota Tangerang". Tesis Magister Perencanaan dan Kebijakan Publik, Fakultas Ekonomi, Universitas Indonesia ini menyatakan bahwa pertumbuhan jalan dan pertumbuhan jumlah kendaraan bermotor yang sangat tidak seimbang menjadikan turunnya fungsi jalan itu sendiri. Dikatakan juga bahwa rendahnya kinerja dan kualitas transportasi public disebabkan banyaknya trayek angkutan umum dan angkutan barang yang beroperasi di wilayah Kota Tangerang. Terakhir, terjadinya ketidakefisienan system transportasi antara lain disebabkan oleh tidak adanya integrasi yang baik antara sub-sistemnya.

Edy Sumirat (2011) berjudul "Dampak Kebijakan Perikanan terbadap Pemberdayaan Masyarakat Nelayan (Studi Kasus Wilayah Provinsi Banten)". Tesis Program Kajian Strategik Ketahanan Nasional Universitas Indonesia ini mengungkapkan bahwa: permasalahan umum pemberdayaan masyarakat pesisir adalah kurangnya modal usaha masyarakat nelayan; rendahnya sumber daya manusia yang ada; kurangnya pemahaman terhadap nilai sumber daya kelautan; kurangnya peran aktif kelembagaan yang ada di wilayah pesisir; masalah lain dalam pembangunan dan pengembangan wilayah pesisir adalah kurangnya pelibatan instansi yang membidangi teknis pemberdayaan 
ARTIKEL

masyarakat, sehingga program-program di wilayah pesisir tidak berjala secara optimal. Kebijakan pemerintah provinsi terhadap dukungan kegiatan pemberdayaan di wilayah pemerintah Provinsi telah mengalokasikan dana untuk diberikan langsung kepada setiap kabupaten. Zona perairan di wilayah Banten pasca otonomi daerah tingkat kerawanan terhaap konflik-konflik antar daerah semakin meningkat seperti perbatasan wilayah penangkapan ikan antar kabupaten.

Samsi AM (2006) melakukan penelitian disertasi berjudul "Pengarub Komitmen Pimpinan, Komitmen Karyawan, Motivasi Kerja, Kepuasan Kerja Terhadap Kinerja Karyawan pada PT Persero Pelabuhan Indonesia III". Disertasi pada Program Pascasarjana Universitas Brawijaya ini menyatakan bahwa sebagai badan usaha milik negara dari sektor perhubungan laut, PT Persero Pelabuhan Indonesia III berorientasi pada laba, sehingga kinerjanya harus selalu ditingkatkan. Menurut Samsi, agar kinerja karyawan, motivasi kerja, kepuasan kerja dan komitmen karyawan meningkat, maka komitmen pimpinan perlu ditingkatkan. Komitmen pimpinan dalam hal ini berkait dengan pengembangan karyawan, menciptakan lingkungan kerja yang kondusif dan memenuhi kebutuhan/kesejahteraan pegawai. Selain itu Samsi menyarankan agar pimpinan PT Pelindo III membuat peraturan yang bersifat fleksibel dalam hal kebijakan pengembangan karyawan, pemberian kompensasi, serta pemberian penghargaan seperti promosi (non finansial) maupun finansial.

\section{METODE PENELITIAN}

Penelitian ini dilakukan dengan pendekatan kualitatif. Pendekatan kualitatif memusatkan perhatiannya pada prinsip-prinsip umum yang mendasari gejala-gejala sosial dalam masyarakat. Objek analisis dalam pendekatan kualitatif adalah makna dari gejala-gejala sosial dan budaya dengan menggunakan kebudayaan dari masyarakat bersangkutan untuk memperoleh gambaran mengenai kategorisasi tertentu (Bungin, 2009:302).

Menurut Creswell (2012) paradigma penelitian kualitatif pada hakikatnya berasal dari Antropologi Budaya dan Sosiologi Amerika. Hanya baru-baru ini saja paradigma tersebut diadopsi oleh para peneliti pendidikan (Borg \& Gall, 1989). Tujuan penelitian kualitatif adalah memahami situasi, peristiwa, kelompok, atau interaksi sosial tertentu (Locke, Spirduso, \& Silverman, 1987). Penelitian ini dapat diartikan sebagai proses 
investigatif yang di dalamnya peneliti secara perlahan-lahan memaknai suatu fenomena sosial dengan membedakan, membandingkan, menggandakan, mengatalogkan, dan mengklasifikasikan objek penelitian (Miles \& Huberman, 1994). Marshall dan Rossman (1989) menyatakan bahwa penelitian ini melibatkan peneliti untuk menyelami setting peneliti. Peneliti memasuki dunia informan melalui interaksi berkelanjutan, mencari makna-makna dan perspektif-perspektif informan.

Dalam upaya mendapatkan data dan informasi baik data primer maupun sekunder yang akurat terkait dengan indikator yang dikaji dalam penelitian digunakan teknik pengumpulan data melalui pengamatan, wawancara, dan dokumentasi tentang objek penelitian yang meliputi tema, kebijakan, dan penyelenggaraan pelayanan informasi kepada publik Pemerintah Provinsi Jawa Barat.

\section{HASIL DAN PEMBAHASAN}

Jawa Barat merupakan salah satu provinsi yang memiliki kondisi alam dengan struktur geologi yang kompleks, dengan luas 35.377,76 KM2. Di wilayah tengah dan selatan Jawa Barat terdapat pegunungan, sementara di bagian utara merupakan dataran rendah. Jawa Barat memiliki hutan yang luasnya mencapai 22,10\% dari luas Jawa Barat, hutan-hutan tersebut memiliki fungsi sebagai hutan konservasi, hutan lindung, dan hutan produksi. Sebagian besar wilayah Provinsi Jawa Barat berbatasan dengan laut sehingga memiliki garis pantai cukup panjang yaitu 755,83 Km. Karena itulah Jawa Barat menawarkan banyak pilihan pantai wisata, Pilihan destinasi pantai wisata ini hampir ada di semua kabupaten di wilayah Jawa Barat. Setidaknya ada 34 pantai wisata yang bisa dikunjungi di seluruh wilayah Provinsi Jawa Barat.

Dengan kondisi geografis yang dimiliki oleh Jawa Barat perlu adanya terobosan cepat untuk membuka akses ekonomi ke berbagai wilayah yang ada di Jawa Barat. Dalam wilayah laut, pembangunan pelabuhan-pelabuhan baru di berbagai wilayah Jawa Barat merupakan salah satu solusi untuk membuka akses baru sehingga muncul sentra ekonomi baru.

Pembangunan dan perbaikan infrastruktur kelautan merupakan solusi berkelanjutan dari Pemerintah Provinsi Jabar yang memiliki efek berantai positif bagi masyarakat Jabar. Hal ini dikarenakan biaya transportasi akan lebih efisien, pergerakan 
orang dan barang akan semakin baik dan lancar, dan juga akan meningkatkan investasi baru yang diharapkan akan memicu percepatan pembangunan di daerah sekitar.

Dalam hal ini, Gubernur Jawa Barat, Ahmad Heryawan pun menyahuti permasalahan tersebut. Berdasarkan Peraturan Gubernur Jawa Barat No.59 Tahun 2016 Pasal 12 tentang Tugas, Pokok, Fungsi dan Rincian Tugas Bidang Transportasi Laut dan ASDP (Angkutan Sungai, Danau dan Penyeberangan) ada beberapa hal yang harus diperhatikan seperti berikut ini:

1. Bidang Transportasi Laut dan ASDP mempunyai tugas pokok menyelenggarakan urusan pemerintahan bidang perhubungan aspek Trasportasi Laut dan ASDP, meliputi kepelabuhanan, lalu lintas angkutan laut dan ASDP serta perkapalan dan kenavigasian.

2. Dalam menyelenggarakan tugas pokok, Bidang Transportasi Laut dan ASDP mempunyai fungsi :

a. penyelenggaraan koordinasi penyusunan dan menghimpun bahan kebijakan teknis transportasi laut dan ASDP;

b. penyelenggaraan transportasi laut dan ASDP meliputi kepelabuhanan, lalu lintas angkutan laut dan ASDP serta perkapalan dan kenavigasian;

c. penyelenggaraan evaluasi dan pelaporan Bidang; dan

d. penyelenggaraan fungsi lain sesuai dengan tugas pokok dan fungsinya.

3. Rincian Tugas Bidang Transportasi Laut dan ASDP:

a. menyelenggarakan pengkajian program kerja Bidang Transportasi Laut dan ASDP;

b. menyelenggarakan koordinasi penyusunan dan menghimpun bahan kebijakan teknis bidang Transportasi Laut dan ASDP;

c. menyelenggarakan pengkajian bahan Seksi Kepelabuhanan;

d. menyelenggarakan pengkajian bahan Seksi Lalu Lintas Angkutan Laut dan ASDP;

e. menyelenggarakan pengkajian bahan Seksi Perkapalan dan Kenavigasian;

f. menyelenggarakan Tindak Lanjut Laporan Hasil Pemeriksaan lingkup Bidang; 
g. menyelenggarakan penyusunan bahan verifikasi, rekomendasi dan menyelenggarakan pemantauan terhadap permohonan dan realisasi bantuan keuangan dan hibah/bantuan sosial di bidang perhubungan;

h. menyelenggarakan penyampaian bahan saran pertimbangan mengenai bidang penataan ruang sebagai bahan perumusan kebijakan Pemerintah Daerah;

i. memimpin seluruh kegiatan Bidang;

j. menyelenggarakan evaluasi dan pelaporan Dinas;

k. menyelenggarakan pengkoordinasian dan pembinaan UPTD;

1. menyelenggarakan telaahan staf sebagai bahan pertimbangan pengambilan kebijakan;

m. menyelenggarakan evaluasi dan pelaporan Bidang Transportasi Laut dan ASDP; dan

n. menyelenggarakan fungsi lain sesuai dengan tugas pokok dan fungsinya.

4. Bidang Transportasi Laut dan ASDP, membawahkan :

a. Seksi Kepelabuhanan;

b. Seksi Lalu Lintas Angkutan Laut dan ASDP

c. Seksi Perkapalan dan Kenavigasian (seperti dikatakan Kepala Bidang Transportasi Laut dan ASDP: H. IDAT ROSANA, S.Sos., M.Si.).

Berikut adalah program-program unggulan transportasi kelautan Dinas Perhubungan Jawa Barat:

1. Kegiatan pengembangan fasilitas pelabuhan penyeberangan dan ASDP di Jawa Barat.

2. Kegiatan penyusunan dokumen kerjasama pembangunan pelabuhan laut di Jawa Barat (Bagian Utara dan Selatan).

3. Kegiatan penyusunan DED (Detail Engineering Design) pembangunan Pelabuhan ASDP di Waduk Cirata.

4. Kegiatan penyusunan AMDAL (Analisis Mengenai Dampak Lingkungan Hidup) pembangunan dermaga kapal wisata (Teluk Palangpang) Kabupaten Sukabumi. 
5. Kegiatan penyusunan DED pembangunan dermaga kapal wisata (Teluk Palangpang) Kabupaten Sukabumi.

6. Kegiatan penyusunan dokumen pemantauan dan pengelolaan lingkungan pembangunan pelabuhan laut pengumpan regional di Jawa Barat.

7. Kegiatan pengadaan sarana dan prasarana keselamatan pelayaran di sungai dan danau di Jawa Barat.

8. Kegiatan penyusunan dokumen upaya pengelolaan lingkungan hidup dan upaya pemantauan lingkungan hidup (UKL/UPL).

9. Kegiatan penyusunan kajian penyelenggaraan kenavigasian pelabuhan pengumpan regional di Teluk Palangpang Kabupaten Sukabumi.

Pemerintah Provinsi Jawa Barat tertarik dengan sistem transportasi yang diterapkan di Propinsi Guangxi Zhuang, Tiongkok, antara lain mengenai pemberlakuan motor listrik di perkotaan. Pemprov Jabar juga akan menawarkan pengembangan sistem transportasi di Bandara Internasional Jawa Barat (BIJB) ke Provinsi Guangxi Zhuang. Dalam hal transportasi laut, dikatakan bahwa pelabuhan terbesar di Tiongkok juga berada di provinsi itu.

Hal itu mengemuka di sela-sela penandatangan nota kesepahaman kerja sama sister province antara Provinsi Jawa Barat dan Propinsi Guangxi Zhuang, di Nanning, Tiongkok , Jumat, 5 Mei 2017. Selain bidang transportasi, Jabar dan Guangxi Zhuang juga akan menjalin kerja sama dalam bidang pariwisata, pendidikan, budaya, perdagangan dan teknologi. "Mudah-mudahan (MoU) ini tonggak kerja sama dengan baik dan disusul kerja sama-kerja sama lainnya," kata Ahmad Heryawan (Aher) sebelum penandatanganan nota kesepahaman.

Ahmad Heryawan menuturkan, pihaknya juga siap menjalin kerja sama di bidang informatika karena Jabar memiliki pakar di bidang tersebut. "Setelah agreement ini, mudah-mudahan ketemu lagi pada peresmian pabrik di Bekasi. Nanti dibentuk tim bersama antara Guangxi dan Jabar untuk merumuskan kerja sama yang lebih nyata," tuturnya.

Khusus mengenai transportasi laut, Kepala Dinas Perhubungan Jawa Barat Dedi Taufik mengatakan pihaknya akan menawarkan kerja sama pembangunan sejumlah pelabuhan di Jabar ke pihak Guangxi Zhuang. "Kita ada Pelabuhan Patimban, Pelabuhan Ratu Regional Seaport, Cirebon, Seaport Cikarang-Bekasi-Laut Inland 
Waterways, Bojong Salawe Regional Seaport, dan Palangpang Local di Ciletuh," katanya.

Wakil Gubernur Guangxi Zhuang, Zhang Xiaoqin, mengapresiasi kerja sama dengan Jabar ini. Menurut dia, provinsinya merupakan satu-satunya provinsi yang berbatasan dengan lautan dan daratan dengan Asean. "Sejak tahun100 SM, kapal-kapal China sudah ke Asean dari pelabuhan ini. Kami sekarang sedang membangun penghubung jalan laut dan infomasi di Asean atau konektivitas dengan negara-negara Asean," katanya.

Terjadinya mobilitas yang tinggi membuat masyarakat terbuka dengan hal-hal yang baru dan peka terhadap informasi serta teknologi. Transportasi Bandung-Jakarta, misalnya, sedang dibangun kereta api cepat berteknologi tinggi (Asmawi et.al., 2018). Begitu juga halnya dengan kesenian. Kebijakan transportasi yang artistik seperti jalanjalan layang di Bandung mendapatkan respon masyarakat yang positif.

Begitulah, kebijakan transportasi itu secara sosiologis telah menimbulkan tiga interaksi yakni interaksi bisnis, interaksi politik, dan interaksi kultural. Interaksi bisnis adalah interaksi tempat kegiatan ekonomi yang menjadi basis materialnya dan ukuranukuran yang digunakan adalah ukuran-ukuran yang bersifat ekonomi. Interaksi politik adalah interaksi yang hubungan budayanya dapat membuat ketergantungan dari suatu budaya terhadap budaya lain. Interaksi kultural adalah sebagai suatu bentuk hubungan dimana basis sosial budaya yang menjadi modalnya. Dalam dimensi interaksi kultural dimungkinkan adanya pertemuan antara dua atau lebih individu pendukung dari unsur kebudayaan yang berbeda. Pertemuan ini mengakibatkan saling sentuh, saling mempengaruhi dan saling mempererat hingga bisa terbentuk suatu kebudayaan baru (Anwar et.al., 2018).

Pembangunan ekonomi bidang maritim merupakan salah satu prioritas program kerja pembangunan. Sasaran pengembangan ekonomi maritim dan kelautan diantaranya termanfaatkannya sumber daya kelautan, tersedianya data dan informasi sumber daya kelautan terintegrasi untuk mendukung pengelolaan sumber daya pesisir dan laut, terwujudnya tol laut dan upaya meningkatkan pelayanan angkutan laut dan konektivitas laut. Untuk mewujudkan sasaran tersebut, wilayah dengan potensi maritim besar perlu didorong untuk melakukan percepatan pengembangan ekonomi kelautan (Agraria \& Tata Ruang, 2016). Letak Provinsi Jawa Barat berhadapan dengan 
Laut Jawa dan Samudera Indonesia sehingga keberadaan transportasi laut sangat penting untuk membuka jalur tranasportasi provinsi dan negara tetangga di Jawa Barat. Selain itu Jawa Barat juga memiliki potensi perikanan yang besar dan perlu dikembangkan. Keberadaan infrastruktur pelabuhan perlu dibangun dengan kualitas dan jumlah yang memadai untuk menunjang berkembangnya sektor maritim dan kelautan.

Dalam kaitannya dengan pengembangan pelabuhan untuk menunjang kegiatan maritim, beberapa indikator bisa menggambarkan kondisi pelabuhan laut, meliputi kegiatan bongkar muat barang, kunjungan kapal, serta jumlah penumpang di pelabuhan umum. Pelabuhan laut di Jawa Barat berada di Kabupaten Sukabumi, Ciamis, Subang, Indramayu, Karawang, Bekasi, dan Kota Cirebon. Pelabuhan Muara Jati di Cirebon meruupakan pelabuhan yang diusahakan di bawah Pelndo II sementara pelabuhan lain diusahakan departemen perhubungan. Seluruh pelabuhan laut di Jawa Barat merupakan pelabuhan perikanan kecuali Pelabuhan Balongan di Indramayu yang merupakan pelabuhan khusus milik Pertamina. Kegiatan di pelabuhan laut Jawa Barat meliputi kegiatan angkutan barang terutama hasil tangkapan ikan, minyak bumi (Balongan), dan barang lainnya, bukan melayani angkutan penumpang. Secara umum kunjungan kapal di Pelabuhan Jawa Barat sampai akir tahun 2014 tercatat 5.910 unit dengan total GRT sebesar 24.953.610 GT

Jawa Barat juga memiliki potensi sumber daya besar pada wilayah pesisir dan laut. Jenis barang yang dibongkar di Pelabuhan yang tidak diusahakan khususnya pelabuhan perikanan di Jawa Barat adalah ikan dan hasil tangkapan lainnya. Sebagian besar produksi ikan terbanyak berasal dari budidaya ikan di kolam yaitu sebanyak 466.638,06 ton dengan nilai produksi sebesar Rp. 7.609.974.149. Produksi ikan yang berasal berasal dari penangkapan, terbanyak berasal dari laut sebanyak 206.156,68 ton dengan nilai produksi sebesar 3.347.090.436 rupiah. Jika dilihat dari jumlah Rumah tangga perikanan, terdapat 2 cara yang dilakukan yaitu dengan cara penangkapan dan dengan budidaya. Berdasarkan data dari dinas perikanan provinsi Jawa Barat pada tahun 2014 yang melakukan penangkapan ikan di laut sebanyak 18.265 orang/kk dan yang melakukan penangkapan di perairan umum sebanyak 24.532. Sedangkan yang melakukan budidaya ikan sebagian besar penduduk lebih memilih budidaya ikan di laut dan kolam masing-masing sebanyak $376.142 \mathrm{kk}$ dan $267.750 \mathrm{kk}$. 


\section{E. KESIMPULAN}

Berdasarkan uraian dan penjelasan di atas, dalam penelitian ini dapat ditarik kesimpulan sebagai berikut:

1. Apa yang muncul ke permukaan, melalui media massa, masyarakat Jawa Barat kebanyakannya menyambut baik kebijakan-kebijakan yang mendukung mudahnya transportasi kelautan.

2. Dengan berbagai kemajuan transportasi kelautan telah terjadi perubahanperubahan dari aspek sosial, budaya, bahkan teknologi.

3. Secara sosiologis, kebijakan-kebijakan transportasi di Jawa Barat telah mengakibatkan interaksi bisnis, interaksi politik, dan interaksi budaya.

4. Selain bersifat ekonomi, sosial, budaya, dan teknologi, kebijakan-kebijakan transportasi pun dapat menambah cita rasa seni masyarakat.

5. Kebijakan transportasi di Jawa Barat bersifat sistemik, yaitu perubahan satu hal akan berakibat pada hal lainnya.

\section{DAFTAR PUSTAKA}

Agraria, K. and Tata Ruang, R.I., 2016. Pengembangan Kawa-san Ekonomi Maritim.

Anwar, Nurul. 2011. Evaluasi Proyek-Proyek Pembangunan Pemerintah, Purwokerto: Percetakan dan Penerbitan UNSOED.

Anwar, R.K., Rusmana, A. and Rahman, M.T., 2018. The Politics Of Information On Traditional Medical Practices In Bandung Barat. MIMBAR, Jurnal Sosial dan Pembangunan, 34(1).

Asmawi, A., Mariana, D. and Sjoraida, D.F., 2018, March. Socializing the policy on public transportation to the community. In IOP Conference Series: Earth and Environmental Science (Vol. 126, No. 1, p. 012168). IOP Publishing.

Asmawi, A., Sjoraida, D.F. and Anwar, R.K., 2017. MASALAH DAN DINAMIKA IMPLEMENTASI KEBIJAKAN PUBLIK TENTANG TRANSPORTASI (Kajian Di Kota Tasikmalaya, Jawa Barat). CosmoGov, 3(2), pp.205-218.

Badan Pusat Statistik (BPS). 2014. Jawa Barat Dalam Angka (Tabun 2008-2013). Bandung: Bappeda Jawa Barat dan Badan Pusat Statistik Propinsi Jawa Barat. 
Chotim, E. R. (2018). KEBIJAKAN BANDUNG TRANSIT AREA (BTA) UNTUK PENINGKATAN KUNJUNGAN WISATA. TEMALI: Jurnal Pembangunan Sosial, 1(1), 33-57.

Deutsch, Karl W. 1986. “The Crisis of State, Government and Opposition” dalam Roy C. Micridis, "Comparative Politics" dalam A.R. Henry Sitanggang, (terj.) Perbandingan Politik, Jakarta: Erlangga.

Gopalakrishna and Leelavathi, D.S. 2011. " Infrastructure and Human development in India: An Inter-state comparison. Journal of Global Economy (ISSN 09753931), Volume 7 No 4, October-December, 2011.

http://dispenda.jabarprov.go.id/2016/05/28/pad-dan-peningkatan-infrastruktur-dijawa-barat/.

Jabarprov.go.id. 2014.Panjang Jalan Menurut Kondisi Jalan dan Tingkat Kewenangan.http://perwakilan.jabarprov.go.id/artikel/datajabar/25.

Mustari, M. and Rahman, M.T., 2010. Peranan pesantren dalam pembangunan pendidikan masyarakat desa. MultiPress.

Nee, Victor. 2005. The New Institutionalism in Economics and Sociology. Center for economy and Society. Ithaca: Cornell University.

Rahman, M. T. (2016). ISLAM AS AN IDEAL MODERN SOCIAL SYSTEM (A Study of Ali Shariati's Thought). JISPO: Jurnal Ilmu Sosial dan Ilmu Politik, 6(1), 42-51.

Sari, A. L. (2017). THE ROLE OF SOCIAL WORKERS IN THE DEVELOPMENT OF TOURISM VILLAGES. JISPO: Jurnal Ilmu Sosial dan Ilmu Politik, 7(2), 1-23.

Srinivasu, B. 2013. Infrastructure of Development and Economic Growth: Prospects and Perspective. Dalam Journal of Business Management \& Social Sciences Research (JBMESSR). ISSN No: 2319-5614 Volume 2.

www.bps.go.id., 2016.

www.id.wikipedia.org.

www.jabar.bps.go.id., 2016. 